Rev. Bras. Saúde Prod. Anim., Salvador, v.16, n.2, p.265-277 abr./jun.., 2015 http://www.rbspa.ufba.br

\title{
Degradabilidade ruminal in situ de silagens de capim-elefante aditivadas com farelo de milho e inoculante da microbiota autóctone
}

\author{
In situ ruminal degradability of silages of elephant grass additivated with corn bran \\ and inoculation of autochthonous microbiota
}

\author{
BEZERRA, Higor Fábio Carvalho ${ }^{1 *}$; SANTOS, Edson Mauro ${ }^{1}$; OLIVEIRA, Juliana \\ Silva de ${ }^{1}$; CARVALHO, Gleidson Giordano Pinto de $^{2}$; CASSUCE, Meiry Rodrigues ${ }^{3}$; \\ PERAZZO, Alexandre Fernandes ${ }^{2}$; FREITAS, Douglas de Souza Souto ${ }^{1}$; SANTOS, \\ Vinicius da Silva ${ }^{1}$
}

\footnotetext{
${ }^{1}$ Universidade Federal da Paraíba, Centro de Ciências Agrárias, Departamento de Zootecnia, Areia, Paraíba, Brasil.

${ }^{2}$ Universidade Federal da Bahia, Escola de Medicina Veterinária e Zootecnia, Departamento de Zootecnia, Salvador, Bahia, Brasil.

${ }^{3}$ Universidade Federal Rural de Pernambuco, Departamento de Zootecnia, Recife, Pernambuco, Brasil.

*Endereço para correspondência: higorfabiozoo@hotmail.com
}

\section{RESUMO}

Objetivou-se avaliar a degradabilidade ruminal in situ da matéria seca, proteína bruta e fibra em detergente neutro de silagens de capim-elefante aditivadas com farelo de milho e inoculante da microbiota autóctone. Para as silagens foi utilizado esquema fatorial $4 \times 2$ (quatro níveis de farelo de milho - 0, 5, 10 e $20 \mathrm{dag} / \mathrm{kgx}$ com e sem inoculante) e cinco repetições, em delineamento inteiramente casualizado. No ensaio de degradabilidade, o delineamento experimental utilizado foi o de blocos ao acaso, com parcelas subdivididas, no qual os três animais representaram os blocos; as silagens representam os sete tempos de incubação dos alimentos no rúmen $(0,6,12,24,48,96$ e 144 horas), as subparcelas. Houve acréscimo da fração solúvel nas silagens com adição do farelo de milho, sendo que no tratamento com $20 \mathrm{dag} / \mathrm{kg}$ proporcionou o maior resultado, com 31,49 e $29,02 \%$, para os tratamentos sem e com inoculante, respectivamente. A fração insolúvel potencialmente degradável, da matéria seca, foi maior nas silagens com $20 \mathrm{dag} / \mathrm{kg}$ de farelo de milho. Na fibra em detergente neutro, os maiores valores fração insolúvel potencialmente degradável foram observados nas silagens sem farelo de milho, 56,52 e 57,19\%, respectivamente, nas silagens de capim sem e com inoculante da microbiota autóctone. A adição de farelo de milho em silagens de capim-elefante melhora a degradabilidade da matéria seca das silagens e diminui a da fibra em detergente neutro.

Palavras-chave: aditivo, incubação ruminal, inoculante microbiano, Pennisetum purpureum, semiárido

\section{SUMMARY}

This study aimed to evaluate the in situ degradability of dry matter, crude protein and neutral detergent fiber of elephant grass silage with corn bran and inoculation of autochthonous microbiota. For the silages used a $4 \times 2$ factorial arrangement (four levels of corn bran - 0, 5, 10 and $20 \mathrm{dag} / \mathrm{kg} \times$ with and without inoculation) and five replications, in a completely randomized design. In degradability trial, the experimental design was a randomized block, split plot in which three animals represented the blocks; silages represent the treatments, and the seven incubation times of food in the rumen $(0$, $6,12,24,48,96$ and 144 hours), the subplots. With the addition of corn bran was increase the soluble fraction in the silages, and so treatments with $20 \mathrm{dag} / \mathrm{kg}$ of corn bran resulted in higher values of the soluble fraction of the dry matter, 31.49 and $29.02 \%$, for treatments with and without inoculant, respectively. The insoluble potentially degradable fraction of dry matter was higher in silages with $20 \mathrm{dag} / \mathrm{kg}$ of corn 
bran. In neutral detergent fiber, higher values of insoluble potentially degradable fraction were observed in the silage without corn bran, 56.52 and $57.19 \%$, respectively, in the silages with and without inoculation of autochthonous microbiota. The addition of corn bran of elephant improves dry matter degradability of silages and decreases of neutral detergent fiber.

Keywords: additive, microbial inoculant, Pennisetum purpureum, ruminal incubation, semiarid

\section{INTRODUÇÃO}

A sazonalidade climática que ocorre no Brasil acarreta em redução da produção de forragem e consequente diminuição da produção animal, fato este que pode ser minimizado pelo armazenamento de forragem na forma de silagem. O uso de espécies forrageiras para produção de volumosos conservados para a alimentação dos rebanhos em confinamento ou em períodos estratégicos de escassez de alimentos é uma alternativa viável para intensificação do sistema produtivo.

Por ser reconhecidamente uma das gramíneas tropicais de maior potencial produtivo de massa forrageira, o capimelefante (Pennisetum purpureum, Schum.) é muito utilizada pelos produtores por também possuir adequado valor nutritivo e ser uma das plantas forrageiras mais utilizadas para conservação na forma de silagem. Entretanto, assim como os demais capins, ele apresenta algumas características desfavoráveis à ensilagem, como baixo teor de matéria seca e elevado poder tampão, quando apresenta um adequado valor nutricional, sendo necessária a utilização de aditivos (ZANINE et al., 2010).

A utilização de aditivos na ensilagem, sejam eles absorventes de umidade ou inoculantes microbianos, tem como objetivo proporcionar um rápido desenvolvimento das bactérias láticas, e ou diminuição das fermentações de microrganismos indesejáveis, como enterobactérias, mofos e leveduras, entre outros. Técnicas essas que devem ser empregadas como formas de minimizar perdas por gases e efluente.

$\mathrm{O}$ aditivo absorvente a ser utilizado em silagens, deve reduzir as perdas no processo fermentativo da ensilagem, entretanto, não deve servir como fonte de substrato para os microorganismos, desta forma, o mesmo ainda fará parte da composição da ração. Nesse contexto, o farelo de milho apresenta-se como um aditivo efetivo na redução de perdas, além de apresentar elevado valor nutricional.

A eficiência de um inoculante depende da quantidade de bactérias presentes, do teor de umidade e da quantidade de açúcares solúveis presentes no material (OHMOMO et al., 2002; SANTOS \& ZANINE, 2006). Dessa forma, a presença de bactérias láticas homofermentativas é extremamente necessária em silagens, como Lactobacillus plantarum, evitando assim perdas de nutrientes através da geração de $\mathrm{CO}_{2}$ por fermentações indesejáveis (SANTOS \& ZANINE, 2006).

Esta pesquisa foi realizada com objetivo de avaliar a degradabilidade da matéria seca e fibra em detergente neutro de silagens de capim-elefante aditivadas com farelo de milho e inoculante da microbiota autóctone.

\section{MATERIAL E MÉTODOS}

O experimento foi desenvolvido utilizando uma capineira de capimelefante (Pennisetum purpureum, Schum.) cv. Roxo já estabelecida no Setor de Bovinocultura de Leite do 
Departamento de Zootecnia do Centro de Ciências Agrárias, da Universidade Federal da Paraíba - UFPB, situada na Mesorregião do Agreste e Microrregião do Brejo Paraibano, Município de Areia, nas coordenadas de $06^{\circ} 57^{\prime} 46^{\prime \prime} \mathrm{e}$ $35^{\circ} 41$ ' 31" W.Gr., com altitude de $623 \mathrm{~m}$. O clima na região, pela classificação de Köppen, é do tipo As' (quente e úmido). De acordo com dados da Estação Meteorológica do Centro de Ciências Agrárias da Universidade Federal da Paraíba a precipitação média anual no município de Areia é de $1400 \mathrm{~mm}$, a temperatura média anual é de $24,5^{\circ} \mathrm{C}$ e a umidade relativa média é de $80 \%$. O quadrimestre mais chuvoso é constituído dos meses de abril a julho, e representa $62 \%$ do total médio anual. $\mathrm{O}$ solo da área é classificado como Latossolo Amarelo (EMBRAPA, 2006). Para atingir os objetivos desse trabalho foi realizado um pré-experimento com intuito de determinar o melhor nível de adição de açúcar no inoculante fermentado, para melhor desenvolvimento da microbiota autóctone.

No pré-experimento utilizou-se um delineamento inteiramente casualizado com três repetições. Os tratamentos foram representados pelos níveis de adição de açúcar $(0 ; 0,5 ; 1 ; 2 ; 4 ; 6$ e $8 \mathrm{dag} / \mathrm{kg}$ na matéria natural). $\mathrm{O}$ capim foi cortado quando apresentava cerca de $2,5 \mathrm{~m}$ de altura e 60 dias de rebrota, com o auxílio de facão, a $10 \mathrm{~cm}$ do solo, e, em seguida, picado em forrageira estacionária, previamente regulada para o tamanho de partículas de $2,0 \mathrm{~cm}$.

No preparo dos inoculantes, $100 \mathrm{~g}$ de forragem picada foi acondicionada em um balão volumétrico e o volume completado com água destilada para um litro. Posteriormente, foram adicionados os teores de açúcar referentes a cada tratamento à solução. $\mathrm{O}$ material permaneceu incubado até atingir o nível de acidez de aproximadamente 4,0, com temperatura em torno $30^{\circ} \mathrm{C}$ e o $\mathrm{pH}$ foi monitorado a cada 4 horas. Após atingir o pH esperado foram coletadas amostras para enumeração de bactérias láticas (BAL). Após monitoramento do $\mathrm{pH}$ e contagem de BAL, foi escolhido o nível de $1 \mathrm{dag} / \mathrm{kg}$, por apresentar maior quantidade de BAL.

$\mathrm{Na}$ fase experimental o capim foi colhido quando apresentava cerca de $2,5 \mathrm{~m}$ de altura e 60 dias de rebrota, assim como na fase pré-experimental. Logo após a colheita, procedeu-se à ensilagem em silos de $\mathrm{PVC}$, com $30 \mathrm{~cm}$ de altura e $15 \mathrm{~cm}$ de diâmetro, dotados de válvula de Bunsen, para escape dos gases. No fundo dos silos, foram adicionados $1,5 \mathrm{~kg}$ de areia para drenagem do efluente, bem como um pano de algodão para evitar o contato da forragem com a areia. A compactação do material foi realizada com soquetes de madeira, colocando-se aproximadamente $2 \mathrm{~kg}$ de forragem fresca por silo. Em seguida, os silos foram fechados, pesados e armazenados em área coberta, em temperatura ambiente, até o momento de abertura.

Antes da compactação do material nos silos, aproximadamente $300 \mathrm{~g}$ de amostra do capim, foram coletadas para posterior determinação da matéria seca (MS), de acordo com Silva \& Queiroz (2002).

Utilizou-se um esquema fatorial $4 \times 2$ (quatro níveis de farelo de milho $\mathrm{x}$ com e sem inoculante) no delineamento inteiramente casualizado, com cinco repetições. Foram utilizados os níveis de farelo de milho: $0 ; 5 ; 10$ e $20 \mathrm{dag} / \mathrm{kg}$, adicionados com base na matéria natural do farelo de milho e do capim.

Um dia antes da ensilagem foi coletado capim para o preparo do inoculante, em que $100 \mathrm{~g}$ de forragem picada foi acondicionada em um balão volumétrico e o volume completado 
para um litro. Posteriormente, foram adicionados $10 \mathrm{~g}$ de açúcar à solução, nível este determinado através da fase pré-experimental. $\mathrm{O}$ material permaneceu em repouso por 16h, tempo esse que levou para o inoculante atingir acidez próxima a 4,0, antes de ser utilizado como inoculante. A dose utilizada no momento da inoculação foi de 1 litro de inoculante para cada 100 $\mathrm{kg}$ de forragem fresca, o que permitiu a adição de $4,6 \quad$ x $10^{7}$ unidades formadoras de colônia (UFC) de bactérias láticas (BAL) por grama de forragem ensilada.

Os silos foram abertos 30 dias após a ensilagem, descartaram-se as porções superior e inferior de cada silo, equivalendo a aproximadamente cinco cm cada, e a porção central foi homogeneizada para então se proceder a retirada de uma amostra de silagem para posteriores analises. As amostras coletadas foram devidamente congeladas, acondicionadas e transportadas para os Laboratórios de Forragicultura e Nutrição Animal do Departamento de Zootecnia da Universidade Federal da Paraíba. Parte das amostras foi pré-seca em estufa de ventilação forçada ar, por 72 horas a $60^{\circ} \mathrm{C}$.

Para determinação da composição bromatológica das silagens no momento da abertura coletaram-se aproximadamente $300 \mathrm{~g}$ de amostra de silagem de cada silo e, em seguida, présecas em estufa de ventilação forçada a $60^{\circ} \mathrm{C}$, até atingir peso constante. Posteriormente, as amostras foram moídas em moinho tipo Willey, com peneira de $1 \mathrm{~mm}$ e acondicionadas em frascos de plástico. A partir destas realizou-se as determinações de matéria seca (MS), segundo metodologias descritas por Silva \& Queiroz (2002). O teor de fibra em detergente neutro (FDN) foi avaliado utilizando as composições de detergente recomendada por Mertens (2002) utilizando o analisador de fibra (Ankom 220). As análises da composição química foram realizadas no laboratório de Análise e Avaliação de Alimentos do Centro de Ciências Agrárias (CCA) da Universidade Federal da Paraíba (UFPB).

Foram utilizados três novilhos Girolando, com peso médio de $350 \pm$ $30 \mathrm{~kg}$, fistulados no rúmen e mantidos em confinamento durante todo $\mathrm{o}$ período experimental, cada animal recebeu uma ração numa relação de volumoso:concentrado de 70:30, sendo o volumoso o capim-elefante. Os ingredientes usados no preparo do concentrado foram milho, farelo de soja, suplemento de vitaminas, sal comum e suplemento mineral. Os animais foram adaptados às rações, por um período de quinze dias, e os volumosos foram incubados nestes, por um período de seis dias, sendo alimentados duas vezes ao dia, pela manhã (8h00) e no período da tarde (16h00).

Em seguida, as amostras foram trituradas em moinho tipo Willey, com peneira de malha de $2 \mathrm{~mm}$, segundo recomendações do NRC (2001). Após a moagem, amostras proporcionais de cada repetição e por tratamento individual foram misturadas para obtenção de uma amostra composta de cada silagem. As amostras compostas foram, então, acondicionadas em sacos de fibra sintética do tipo TNT, gramatura 100, com dimensões de $9 \times 6,5 \mathrm{~cm}$, na quantidade de aproximadamente $2,2 \mathrm{~g}$ de $\mathrm{MS} / \mathrm{saco}$, a fim de manter relação próxima a $20 \mathrm{mg}$ de $\mathrm{MS} / \mathrm{cm}^{2}$ de área superficial do saco (NOCEK, 1988). Os períodos de incubação corresponderam aos tempos de $0,6,12,24,48,96$, e 144 horas, sendo que o tempo zero hora correspondeu à lavagem dos sacos em água corrente, para determinação da 
fração solúvel. Os sacos foram colocados em ordem inversa e em duplicata para serem retirados todos ao mesmo tempo, promovendo lavagem uniforme do material na ocasião da retirada do rúmen, onde os sacos foram presos a um cordão de náilon com $30 \mathrm{~cm}$ preso à tampa da cânula e ancorados com peso de $0,5 \mathrm{~kg}$ preso à extremidade do cordão de náilon.

Após a remoção de todos os sacos do rumem, juntamente com o tempo 0 horas, os sacos foram lavados exaustivamente em água corrente e em seguida submetidos à secagem em estufa de ar com ventilação forçada, a $60^{\circ} \mathrm{C}$ por 72 horas, e pesados para determinação do desaparecimento da MS. O resíduo obtido após esta etapa foi utilizado para as análises de $\mathrm{PB}$ e FDN, segundo metodologias descritas por Silva \& Queiroz (2002) e Mertens (2002), respectivamente.

Os dados de degradabilidade in situ da MS e FDN foram obtidos pela diferença de peso encontrada para cada componente entre as pesagens feitas antes e após a incubação ruminal e expressos em porcentagem.

$\mathrm{O}$ delineamento experimental utilizado foi o de blocos ao acaso, com parcelas subdivididas, no qual os três animais representaram os blocos; as silagens representam as parcelas; e os sete horários de incubação dos alimentos no rúmen, as subparcelas. Com o auxílio do SAEG, 2007 - Sistema de Análises Estatísticas e Genéticas (RIBEIRO JUNIOR, 2001), foram calculadas as taxas de degradação da matéria seca utilizando-se a equação proposta por Ørskov \& McDonald (1979):

$\mathrm{Dt}=\mathrm{A}+\mathrm{B} \times\left(1-\mathrm{e}^{\text {-ct }}\right)$, em que: $\mathrm{Dt}=$ fração degradada no tempo t (\%); $\mathrm{A}=$ fração solúvel (\%); B = fração insolúvel potencialmente degradável (\%); c = taxa de degradação da fração B (h-1); e t = tempo (horas).
A degradabilidade da FDN foi estimada utilizando-se o modelo de Mertens \& Loften (1980): Rt= B x (1 - $\left.\mathrm{e}^{\text {-ct }}\right)$, em que $\mathrm{Rt}=$ fração degradada no tempo $\mathrm{t} ; \mathrm{c}=$ taxa de degradação da fração B (h-1); e $\mathrm{t}=$ tempo (horas). Após os ajustes da equação de degradação da FDN, procedeu- se à padronização de frações, conforme proposto por Waldo et al. (1972), utilizando-se as equações: $B_{P}=$ $\mathrm{B} /(\mathrm{B}+\mathrm{I}) \times 100 ; \mathrm{I}_{\mathrm{P}}=\mathrm{I} /(\mathrm{B}+\mathrm{I}) \times 100, \mathrm{em}$ que: $\mathrm{B}_{\mathrm{P}}=$ fração potencialmente degradável padronizada $(\%) ; \mathrm{I}_{\mathrm{P}}=$ fração indigestível padronizada (\%); e $\mathrm{B}, \mathrm{I}=$ fração indigestível.

Os coeficientes não-lineares $\mathrm{A}, \mathrm{B}$ e c foram estimados por meio de procedimentos iterativos de GaussNewton. A degradabilidade efetiva (DE) da matéria seca (MS) e da proteína bruta (PB) no rúmen foi calculada utilizando-se o modelo:

$\mathrm{DE}=\mathrm{A}+(\mathrm{B} \times \mathrm{c} / \mathrm{c}+\mathrm{k})$, em que $\mathrm{k}$ corresponde à taxa estimada de passagem das partículas no rúmen, as quais foram utilizadas: 2 ; 5 e 8 horas, simulando taxas de passagem baixa, media e alta, respectivamente.

No cálculo da digestibilidade efetiva da FDN, utilizou-se o modelo: $\mathrm{DE}=\mathrm{BP} \mathrm{x}$ $\mathrm{c} /(\mathrm{c}+\mathrm{k})$, em que BP é a fração potencialmente degradável (\%) padronizada.

\section{RESULTADOS E DISCUSSÃO}

Os teores de matéria seca (MS), matéria orgânica (MO), proteína bruta (PB), extrato etéreo (EE), carboidratos totais (CHOT) e carboidratos não fibrosos (CNF), aumentaram linearmente $(\mathrm{P}<0,05)$, em função dos níveis do farelo de milho (Tabela 1). Esse resultado era esperado, em função da composição do farelo de milho possuir 
Rev. Bras. Saúde Prod. Anim., Salvador, v.16, n.2, p.265-277 abr./jun.., 2015 http://www.rbspa.ufba.br ISSN 15199940

teores mais elevados destes constituintes.

$\mathrm{O}$ aumento dos teores de CNF e CHOT podem estar associados aos açúcares adicionados ao inoculante e que não foram utilizados pelos microrganismos durante a fermentação do mesmo, desta forma aumentando os teores destes componentes nas silagens.

A fibra em detergente neutro (FDN) teve um decréscimo linear $(\mathrm{P}<0,05)$, apresentando comportamento inverso às demais variáveis, pois quando se aumenta os níveis de farelo de milho, ocorre uma diminuição nos teores de FDN presente nas silagens, devido o capim elefante possuir maior quantidade de fibra que o farelo de milho. Por consequência da adição do farelo ocorreu o acréscimo nos teores de CNF.

Tabela 1. Valores médios dos teores de matéria seca (MS), matéria orgânica (MO), proteína bruta $(\mathrm{PB})$, extrato etéreo (EE), fibra em detergente neutro (FDN), carboidratos totais (CHOT) e carboidratos não fibrosos (CNF) de silagens de capim-elefante aditivadas com diferentes níveis de farelo de milho e com ou sem inoculante da microbiota autóctone

\begin{tabular}{lccccccc}
\hline \multirow{2}{*}{ Inoculante } & $\mathrm{MS}^{1}$ & $\mathrm{MO}^{2}$ & $\mathrm{~PB}^{3}$ & $\mathrm{EE}^{4}$ & $\mathrm{FDN}^{5}$ & $\mathrm{CHOT}^{6}$ & $\mathrm{CNF}^{7}$ \\
\cline { 2 - 8 } & dag/kg MN & \multicolumn{7}{c}{$\mathrm{dag} / \mathrm{kg} \mathrm{MS}-$} & & \\
\hline Sem & 25,36 & $91,56^{\mathrm{b}}$ & 8,47 & 3,94 & 56,68 & $79,18 \mathrm{~b}$ & $22,50^{\mathrm{b}}$ \\
\hline Com & 25,57 & $92,23^{\mathrm{a}}$ & 8,41 & 4,23 & 56,08 & $80,25 \mathrm{a}$ & $24,17^{\mathrm{a}}$ \\
\hline \multicolumn{7}{c}{ Níveis de Farelo $(\mathrm{dag} / \mathrm{kg})$} \\
\hline 0 & 20,84 & 90,13 & 7,13 & 3,15 & 68,57 & 77,11 & 8,54 \\
5 & 22,86 & 90,86 & 8,28 & 4,01 & 59,55 & 77,71 & 18,16 \\
10 & 25,15 & 92,56 & 9,12 & 4,14 & 53,03 & 80,99 & 27,95 \\
20 & 33,01 & 94,05 & 9,23 & 5,06 & 44,36 & 83,04 & 38,68 \\
\hline $\mathrm{CV}^{8}(\%)$ & 5,02 & 0,80 & 9,26 & 15,83 & 4,58 & 1,96 & 14,19
\end{tabular}

Médias seguidas de mesma letra na coluna não diferem entre si pelo teste de Tukey a $5 \%$ de probabilidade.

$\mathrm{CV}=$ coeficiente de variação.

$\begin{array}{ll}{ }^{1} \hat{Y}=20,0818+0,6157 * X & r^{2}=97,39 \% \\ { }^{2} \hat{Y}=90,1254+0,2028 * X & r^{2}=97,14 \% \\ { }^{3} \hat{Y}=7,5764+0,0993 * X & r^{2}=76,65 \% \\ { }^{4} \hat{Y}=3,3070+0,0892 * X & r^{2}=94,92 \% \\ { }^{5} \hat{Y}=66,7032-1,1795 * X & r^{2}=93,51 \% \\ { }^{6} \hat{Y}=76,9436+0,3166 * X & r^{2}=96,78 \% \\ { }^{7} \hat{Y}=11,7412+1,3806 * X & r^{2}=99,83 \%\end{array}$

As silagens produzidas com capimelefante sem a adição do farelo de milho apresentaram os menores valores da fração "a" (solúvel) da MS sem e com inoculante da microbiota autóctone $(17,55$ e $17,98 \%$, respectivamente) (Tabela 2). Carvalho et al. (2008) que avaliaram a degradabilidade ruminal da silagem de capim-elefante submetido a um corte de uniformização após 50 dias de rebrota obteve valor de $21,4 \%$ da fração "a", valor este próximo aos relatados neste trabalho. Para a mesma avaliação da silagem de capim-elefante 
aos 120 dias de crescimento, Teixeira et al. (2008) encontrou valor de $11 \%$ da fração "a". Este comportamento é explicado devido o aumento da idade do capim estar relacionado com a redução da porção solúvel e aumento da fibra em detergente neutro.

Visto que a fração "a" da matéria seca representa a porção do alimento que está prontamente disponível para os microrganismos ruminais, observa-se que o farelo de milho contribuiu para o acréscimo desta fração nas silagens, pois com o aumento dos níveis de farelo de milho, elevou-se também a fração "a" das silagens, tendo em vista que o farelo de milho possui elevados valores desta fração em sua composição. Apresentando assim os tratamentos com $20 \mathrm{dag} / \mathrm{kg}$ de farelo de milho os valores da fração "a" na MS de 31,49 e 29,02\%, para os tratamentos sem e com inoculante, respectivamente (Tabela 2).

Tabela 2. Valores (\%) dos parâmetros da degradabilidade das frações a, b, taxa de degradação da fração B (c) e I da matéria seca de silagens de capim-elefante em função de níveis de farelo de milho com e sem inoculante

\begin{tabular}{lcccc}
\hline & \multicolumn{4}{c}{ Níveis de farelo de milho (dag/kg) } \\
\cline { 2 - 4 } Parâmetro & 0 & \multicolumn{4}{c}{ Sem inoculante } \\
\cline { 2 - 4 } & \multicolumn{4}{c}{20} \\
\hline Fração a & 17,55 & 23,72 & 26,64 & 31,49 \\
Fração B & 52,42 & 52,16 & 51,64 & 57,44 \\
$\mathrm{C}\left(\mathrm{h}^{-1}\right)$ & 0,0217 & 0,0218 & 0,0253 & 0,0193 \\
Fração I & 30,03 & 24,12 & 21,72 & 11,07 \\
\hline \multicolumn{5}{c}{ Com inoculante } \\
\hline Fração a & 17,98 & 23,99 & 24,12 & 29,02 \\
Fração B & 50,94 & 53,94 & 53,80 & 59,95 \\
C $\left(\mathrm{h}^{-1}\right)$ & 0,0209 & 0,0201 & 0,0282 & 0,0203 \\
Fração I & 31,08 & 22,07 & 22,08 & 11,03 \\
\hline
\end{tabular}

$\mathrm{A}$ = fração solúvel em água (da MS) que desaparece dos sacos no tempo zero; $\mathrm{B}=$ fração insolúvel em água, mas potencialmente degradável em função do tempo; $\mathrm{c}=$ taxa de degradação ruminal da fração $\mathrm{B}$, expressa em \%/h; I = fração indigestível no rúmen da matéria seca (MS), ou seja, é o resíduo do alimento remanescente nos sacos após 144 horas de incubação.

Além dos maiores valores da fração $\mathrm{A}$, a fração $B$ (insolúvel potencialmente degradável) da MS também foi maior nas silagens com $20 \mathrm{dag} / \mathrm{kg}$ de farelo de milho. Isso é explicado pelo fato do farelo de milho possuir elevado teor de amido e este possuir alta fração potencialmente degradável, se tornando disponível ao sistema ruminal. Passini et al. (2004) avaliando a degradabilidade in situ de grão de milho em diferentes formas de processamento, observaram que o grão de milho moído fino, forma utilizada neste experimento, possui alto teor da fração B, com cerca de 89,70\% desta fração na MS, por isso o aumento da fração B.

Com relação à utilização do inoculante da microbiota autóctone, não houve grande variação nos valores das frações "a" e B entre as silagens com e sem o inoculante (Tabela 2), tendo em vista que $o$ inoculante da microbiota autóctone não proporciona nenhuma alteração significativa na composição bromatológica (Tabela 1), desta forma, não alterando também a sua degradabilidade. Resultados semelhantes 
foram encontrados por Gimenes et al. (2006), que avaliando silagens de milho com a adição de inoculante microbianos e enzimáticos, não encontrou grande variação dos valores da degradabilidade das frações A e B entre as silagens com e sem a utilização de inoculante.

$\mathrm{Na}$ FDN, os maiores valores de $\mathrm{B}_{\mathrm{P}}$ foram observados nas silagens de capim sem farelo de milho, sem e com inoculante 56,52 e $57,19 \%$, respectivamente (Tabela 3 ), ocasionado pelo maior teor de FDN nessas silagens. A relação entre a quantidade de carboidratos da parede celular e seu teor de lignina são os fatores que mais afetam a qualidade das gramíneas tropicais. Assim, o maior teor de amido presente no farelo de milho em comparação ao capim-elefante ensilado, pode ter proporcionado maior desenvolvimento de bactérias amilolíticas em relação às celulolíticas, e consequentemente com a maior adição do farelo de milho diminuiu assim a utilização da fibra haja vistas ao fato de haver material de mais fácil utilização, no caso, o farelo de milho.

Tabela 3. Valores (\%) dos parâmetros da degradabilidade das frações $B_{p}$, taxa de degradação da fração B (c), L e I da Fibra em Detergente Neutro de silagens de capim-elefante em função de níveis de farelo de milho com ou sem inoculante

\begin{tabular}{lcccc}
\hline & \multicolumn{4}{c}{ Níveis de farelo de milho (dag/kg) } \\
\cline { 2 - 4 } Parâmetro & 0 & \multicolumn{4}{c}{ Sem inoculante } \\
\cline { 2 - 4 } & \multicolumn{4}{c}{50} \\
\hline Fração $\mathrm{B}_{\mathrm{p}}$ & 56,52 & 55,90 & 50,08 & 49,63 \\
$\mathrm{C}\left(\% \mathrm{~h}^{-1}\right)$ & 0,0231 & 0,0213 & 0,0202 & 0,0207 \\
Latência $(\mathrm{h})$ & 3,68 & 5,01 & 2,78 & 1,48 \\
Fração I & 41,69 & 39,53 & 41,44 & 36,17 \\
\hline & \multicolumn{4}{c}{ Com inoculante } \\
\hline Fração $\mathrm{B}_{\mathrm{p}}$ & 57,19 & 52,23 & 50,34 & 49,52 \\
$\mathrm{C}\left(\% \mathrm{~h}^{-1}\right)$ & 0,0199 & 0,0205 & 0,0195 & 0,018 \\
Latência $(\mathrm{h})$ & 1,34 & 9,62 & 3,00 & 1,09 \\
Fração I & 41,25 & 39,47 & 38,23 & 35,32 \\
\hline
\end{tabular}

$\mathrm{B}_{\mathrm{p}}=$ fração potencialmente degradável no rúmen FDN; $\mathrm{c}=$ taxa de degradação ruminal da fração $\mathrm{B}_{\mathrm{p}}$, expressa em \%/h; L = tempo de latência $(\mathrm{h}) ; \mathrm{I}=$ fração indigestível no rúmen da Fibra em Detergente Neutro (FDN), ou seja, é o resíduo do alimento remanescente nos sacos após 144 horas de incubação.

A taxa de degradação da fração potencialmente degradável da matéria seca varia de 2 a $8 \%$ /hora (NRC, 1985). Apesar do aumento nas frações A e B, as taxas de degradação da MS em \%/hora (fração C) mantiveram-se constantes, mantendo-se sempre em torno de $2 \%$ /hora.

Observou-se aumento crescente da degradabilidade potencial da MS com a inclusão dos níveis de farelo de milho.
Os maiores valores foram observados quando adicionado níveis de $20 \mathrm{dag} / \mathrm{kg}$ de farelo de milho nas silagens, 88,93 e $88,97 \%$ sem e com inoculante, respectivamente e os menores valores foram observado na silagem do capim sem adição do farelo, 69,97 e 68,92\% sem e com inoculante, respectivamente (Tabela 4).

$\mathrm{O}$ aumento da degradabilidade potencial com a inclusão das níveis de farelo de 
Rev. Bras. Saúde Prod. Anim., Salvador, v.16, n.2, p.265-277 abr./jun.., 2015 http://www.rbspa.ufba.br ISSN 15199940

milho pode ser atribuído a maior degradabilidade que este farelo possui, considerando-se que sua composição possui constituintes de fácil solubilidade em maior quantidade que no capim. Passini et al. (2004) observaram que o grão de milho independentemente da forma a qual seja processado, possui degradabilidade potencial da MS de praticamente $100 \%$, o que explica essa elevação da degradabilidade potencial das silagens com a inclusão das níveis de farelo de milho.
A mesma tendência observada para a degradabilidade potencial foi constatada para a degradabilidade efetiva da MS, ou seja, os valores foram maiores nas silagens com a adição farelo de milho (Tabela 4). Assim, o elevado teor de carboidratos solúveis do farelo de milho provavelmente foi o responsável pelos maiores valores de degradabilidade efetivas das silagens com a adição do mesmo.

Tabela 4. Degradabilidade potencial (DP) e efetiva (DE) da matéria seca (MS) e da fibra em detergente neutro (FDN) de silagens de capim-elefante (CE)

\begin{tabular}{lcccc}
\hline \multirow{2}{*}{ Silagens } & \multirow{2}{*}{$\begin{array}{c}\text { Degradabilidade } \\
\text { Potencial }\end{array}$} & \multicolumn{3}{c}{ Degradabilidade efetiva } \\
\cline { 3 - 5 } & \multicolumn{2}{c}{ Matéria seca $(\%)$} & 5 & 8 \\
\cline { 3 - 4 } & 69,97 & 44,83 & 33,41 & 28,73 \\
CE SI & 68,92 & 44,01 & 33,00 & 28,53 \\
CE CI & 75,88 & 50,92 & 39,56 & 34,89 \\
CE +5dag/kg FM SI & 77,93 & 51,03 & 39,46 & 34,82 \\
CE +5 dag/kg FM CI & 78,28 & 55,48 & 43,99 & 39,05 \\
CE +10 dag/kg FM SI & 77,92 & 55,60 & 43,52 & 38,14 \\
CE +10 dag/kg FM CI & 88,93 & 59,70 & 47,49 & 42,65 \\
CE +20 dag/kg FM SI & 88,97 & 59,22 & 46,33 & 41,15 \\
CE +20 dag/kg FM CI & Fibra em detergente neutro (\%) & & 12,66 \\
& 56,52 & 30,29 & 17,86 & 11,39 \\
\hline CE SI & 57,19 & 28,52 & 16,28 & 11,75 \\
CE CI & 55,90 & 28,83 & 16,70 & 10,65 \\
CE +5dag/kg FM SI & 52,23 & 26,44 & 15,19 & 10,10 \\
CE +5 dag/kg FM CI & 50,08 & 25,16 & 14,41 & 9,87 \\
CE +10 dag/kg FM SI & 50,34 & 24,85 & 14,12 & 10,20 \\
CE +10 dag/kg FM CI & 49,63 & 25,24 & 14,53 & 9,10 \\
CE +20 dag/kg FM SI & 49,52 & 23,46 & 13,11 & \\
CE +20 dag/kg FM CI & & &
\end{tabular}

$\mathrm{CE}=$ capim-elefante; $\mathrm{FM}=$ farelo de milho.

Considerando a taxa de passagem de $2 \% /$ hora, excetuando-se a silagem sem a adição de farelo de milho, que apresentou de 44,01 e 44,83\% de degradabilidade efetiva, para os tratamentos com e sem a utilização do inoculante da microbiota autóctone, respectivamente, todas as outras silagens (capim com 5, 10 e $20 \mathrm{dag} / \mathrm{kg}$ de farelo de milho) apresentaram degradabilidade efetiva da MS acima de $50 \%$ (Tabela 4).

A degradação potencial da FDN das silagens com farelo de milho foi menor que a das silagens sem a adição do farelo e não teve influência da adição ou não do inoculante, o que pode estar relacionado ao teor de carboidratos solúveis do farelo de milho ser mais elevado do que o do capim-elefante. 
Como relatado anteriormente, essa maior quantidade de carboidratos presente no milho pode ter proporcionado a elevação das populações microbianas amilolíticas e consequentemente diminuição nas populações de bactérias celulolíticas.

Os valores obtidos neste estudo para a degradabilidade potencial da FDN das silagens com capim-elefante com ou sem a utilização do farelo de milho $(57,19$ e $56,52 \%$ respectivamente) foram inferiores aos descritos por Carvalho et al. (2008), que avaliaram a degradabilidade ruminal do capimelefante ensilado aos 50 dias de rebrota emurchecido ou com diferentes níveis de farelo de cacau e observaram degradabilidade potencial de $68 \%$ da FDN no tratamento somente com capim elefante. Sabe que, com o crescimento das plantas, a parede celular se desenvolve acumulando lignina, portanto, acredita-se que o estádio de maturação em que o capim-elefante foi cortado neste experimento, cerca de 60 dias de rebrotação, tenha sido a causa dos menores valores de degradabilidade potencial da FDN.

A degradabilidade efetiva da FDN apresentou maiores valores para os tratamentos sem a utilização do farelo, e apresentou valores semelhantes pra a adição ou não do inoculante. $\mathrm{O}$ que pode estar associado ao maior desenvolvimento de bactérias amilolíticas, como já relatado sobre os dados da Tabela 2.

Observa-se que os potenciais de degradação da MS das silagens com farelo de milho foram maiores que das silagens sem farelo, durante todos os períodos de incubação, destacando-se as silagens com a adição de $20 \mathrm{dag} / \mathrm{kg}$ de farelo de milho, que obtiveram os maiores potenciais de degradabilidade da MS (Figura 1). O potencial máximo de degradação da MS de todas as silagens foi obtido com 144 horas de incubação.

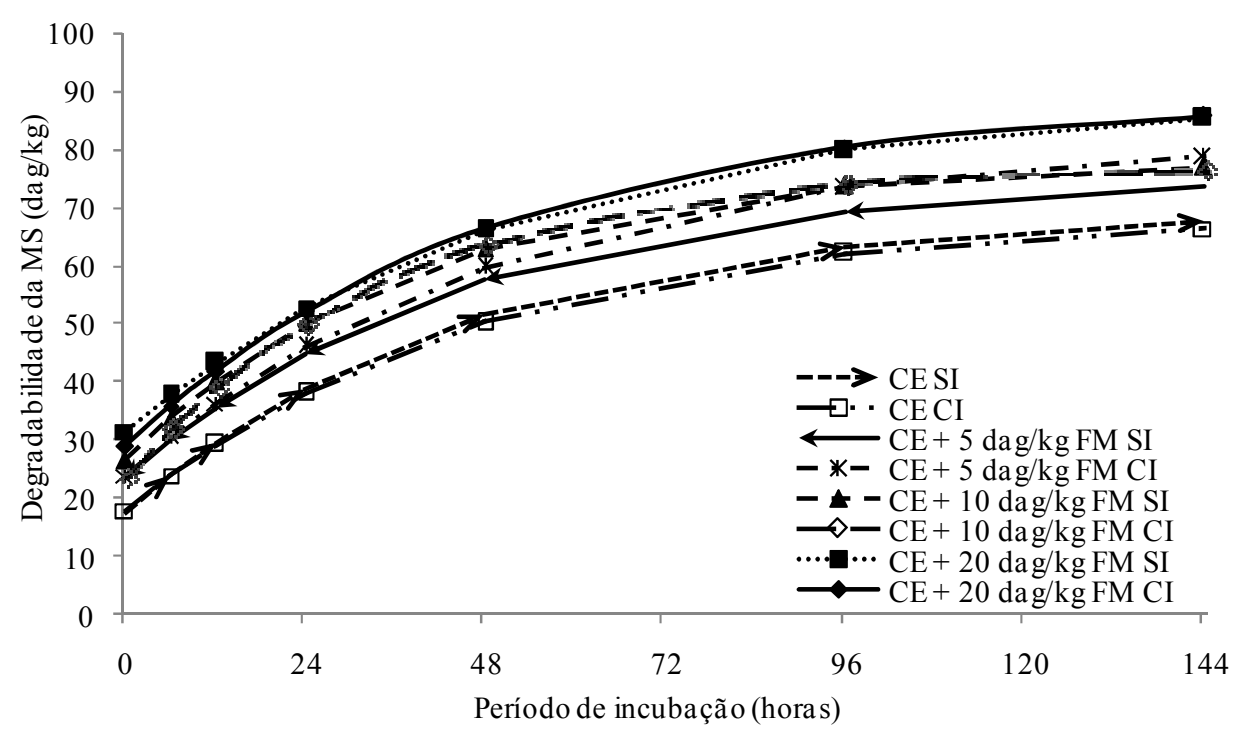

Figura 1. Degradabilidade da matéria seca (MS) de silagens de capimelefante (CE) aditivadas com farelo de milho (FM) e sem (SI) e com inoculante $(\mathrm{CI})$ da microbiota autóctone. Estimada pela equação: $\mathrm{Dt}=\mathrm{A}+\mathrm{B} \times(1-\mathrm{e}-\mathrm{ct})$ 
Após 144 horas de incubação ruminal, os valores de degradação da MS das silagens são elevados (acima de 65\%), no entanto, não é observado estabilização da degradabilidade das silagens, demonstrando que as silagens ainda possuíam potencial de degradabilidade após as 144 horas, (Figura 1). Porém é possível perceber a desaceleração que ocorre a partir das 96 horas de incubação das silagens no rúmen.

A curva de desaparecimento da FDN (Figura 2) comprova que as silagens de capim-elefante diferiram quanto à taxa de desaparecimento da fibra. Até as primeiras 24 horas de incubação ruminal, os valores de degradação da FDN mantiveram-se próximos (aproximadamente 20\%), contudo, a partir deste tempo, os valores observados para as silagens sem a adição farelo de milho foram maiores. Fato este provavelmente relacionado com maior desenvolvimento de bactéria amilolíticas, como relatado anteriormente.

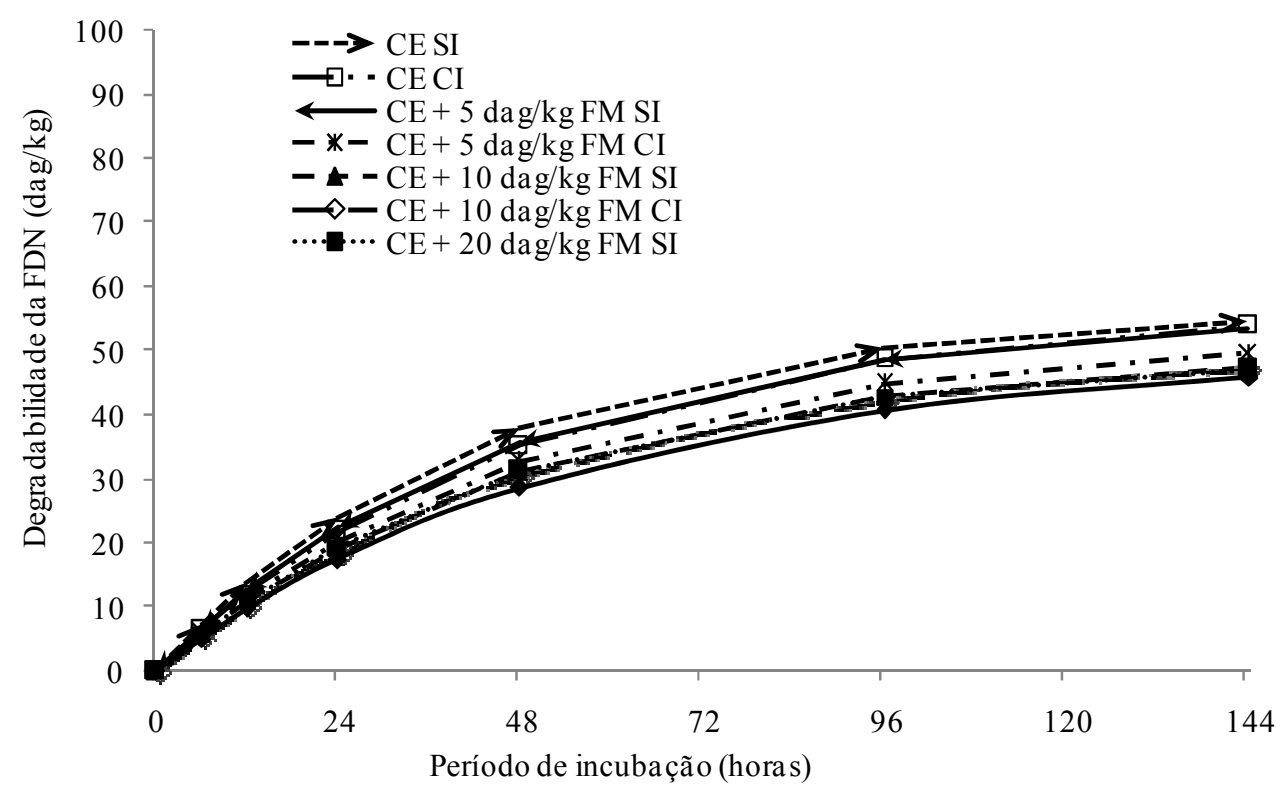

Figura 2. Degradabilidade da fibra em detergente neutro (FDN) de silagens de capim-elefante (CE) aditivadas com farelo de milho (FM) e sem (SI) e com inoculante (CI) da microbiota autóctone. Estimada pela equação: $\mathrm{Rt}=\mathrm{B} \times \mathrm{e}-\mathrm{ct}+\mathrm{I}$

Fato semelhante ao potencial de degradabilidade da MS foi observado para o potencial de degradabilidade da FDN, em que, após 144 horas de incubação ruminal, os valores de degradação das silagens são os mais elevados (acima de 45\%), no entanto, não é observado estabilização da degradabilidade das silagens, demonstrando que as silagens ainda possuíam potencial de degradabilidade após as 144 horas, (Figura 2). Porem é possível perceber a desaceleração que ocorre a partir das 96 horas de incubação ruminal.

A adição do farelo de milho proporcionou aumento da degradabilidade da MS, entretanto 
Rev. Bras. Saúde Prod. Anim., Salvador, v.16, n.2, p.265-277 abr./jun.., 2015 http://www.rbspa.ufba.br ISSN 15199940

proporcionou diminuição da degradação da FDN, sendo assim indicado que em silagens com a adição do farelo de milho ou de outros aditivos que estimulem o aumento de outros microrganismos, que não sejam celulolíticos, dentro do rumem, a necessidade que durante a formulação de rações, incluam-se aditivos como é o caso da ureia, que estimulem a produção das populações de microrganismos que proporcionem melhor utilização da fibra, incrementando a degradação da fibra em detergente neutro.

A utilização do inoculante da microbiota autóctone não provoca alterações sobre a degradabilidade de silagens de capim-elefante.

A adição do farelo de milho proporciona melhoria na degradabilidade da matéria seca e diminui a da fibra em detergente neutro em silagens de capim-elefante.

\section{REFERÊNCIAS}

CARVALHO, G.G.P.; GARCIA, R.; PIRES, A.J.V. DETMANN, E.; PEREIRA, O.G.; FERNANDES, F.E.P. Degradação ruminal de silagem de capim-elefante emurchecido ou com diferentes níveis de farelo de cacau.

Revista Brasileira de Zootecnia, v.37, n.8, p.1347-1354, 2008.

EMPRESA BRASILEIRA DE PESQUISA AGROPECUÁRIA EMBRAPA. Centro Nacional de Pesquisa de Solos. Sistema brasileiro de classificação de solos. 2.ed. Rio de Janeiro: EMBRAPA Solos, 2006. 306p.

GIMENES, A.L.G.; MIZUBUTI, I.Y.; MOREIRA, F.B.; PEREIRA, E.S.; RIBEIRO, E.L. de A.; MORI, R.M.
Degradabilidade in situ de silagens de milho confeccionadas com inoculantes bacteriano e/ou enzimático. Acta

Scientiarum Animal Sciences, v.28, n1, p.11-16, 2006.

MERTENS, D.R. Gravimetric determination of amylase-treated neutral detergent fiber in feeds with refluxing in beaker or crucibles: collaborative study. Journal of AOAC International, v.85, p1217-1240, 2002.

MERTENS, D.R.; LOFTEN, J.R. The effect of starch on forage fiber digestion kinetics in vitro. Journal of Dairy

Science, v.63, p.1437-1446, 1980.

NATIONAL RESEARCH COUNCIL NRC. Ruminant nitrogen usage. Washington, D.C.: National Academy Press, 1985. 138p.

NATIONAL RESEARCH COUNCIL NRC. Nutrient requirements of dairy cattle.7.ed. Washington, D.C.: National Academy Press, 2001. 450p.

NOCEK, J.E. In situ and other methods to estimate ruminal protein and energy digestibility: a review. Journal of Dairy Science, v.71, n.5, p.2051-2069, 1988.

OHMOMO, S.; TANAKA, O.;

KITAMOTO, H.K.; CAI, I. Silage and microbial performance, old history but new problem. JARQ, v.40, n.2, p.59$71,2002$.

ØRSKOV, E.R.; McDONALD, I. The estimation of protein degradability in the rumen from incubation measurements weighted according to rate of passage. Journal Agricultural Science, v.92, n.1, p.449-453, 1979.

PASSINI, R.; BORGATTI, L.M.O.; FERREIRA, F.A.; RODRIGUES, 
Rev. Bras. Saúde Prod. Anim., Salvador, v.16, n.2, p.265-277 abr./jun.., 2015 http://www.rbspa.ufba.br

P.H.M. Degradabilidade no rúmen bovino de grãos de milho processados de diferentes formas. Pesquisa Agropecuária Brasileira, v.39, n.3, p.271-276, 2004.

RIBEIRO JUNIOR, J.I. Análises estatísticas no SAEG (Sistema para análises estatísticas). Viçosa, MG: UFV, 2001. 301p.

SANTOS E.M.; ZANINE, A.M.

Silagem de gramíneas tropicais.

Colloquium Agrariae, v.2, n.1, p.3245, 2006.

SILVA, D.J.; QUEIROZ, A.C. Análises de alimentos (métodos químicos e biológicos). 3 ed. Viçosa, MG: UFV, 2002. 235p.

TEIXEIRA, F.A.; VELOSO, C.M.; PIRES, A.V.; SILVA, F.F. da; NASCIMENTO, P.V.N.; CARVALHO, G.G.P. de. Degradação ruminal da silagem de capim-elefante aditivado com cana-de-açúcar e farelo de cacau. Ciência e Agrotecnologia, v.32, n.3, p.948-954, 2008.

WALDO, D.R.; SMITH, L.W.; COX, E.L. Model of cellulose disappearance from the rumen. Journal of Dairy Science, v.55, p.125-129, 1972.

ZANINE, A.M.; SANTOS, E.M.; DOREA, J.R.R.; DANTAS, P.A.de S.; SILVA, T.C da; PEREIRA, O.G. Evaluation of elephant grass with adition of cassava scrapings. Revista Brasileira de Zootecnia, v.39, n.12, p.2611-2616, 2010.

Data de recebimento: $23 / 04 / 2014$

Data de aprovação: 23/05/2015 